\title{
Faktor Risiko Non-genetik Inhibitor Faktor VIII pada Pasien Hemofilia A
}

\author{
Ahmad Saifudin, Harry Raspati Achmad, Lelani Reniarti \\ Departemen Ilmu Kesehatan Anak Fakultas Kedokteran Universitas Padjadjaran/Rumah Sakit Hasan Sadikin, Bandung
}

Latar belakang. Terbentuknya inhibitor atau antibodi terhadap FVIII pada pasien hemofilia A menyebabkan FVIII eksogen yang diberikan tidak dapat berfungsi. Penyebab bersifat multifaktorial terdiri atas faktor genetik dan lingkungan. Beberapa penelitian telah dilakukan untuk mengetahui faktor risiko terbentuknya inhibitor, akan tetapi masih terdapat pendapat yang kontroversial.

Tujuan. Menentukan faktor risiko non-genetik inhibitor faktor VIII pada pasien hemofilia A.

Metode. Penelitian desain potong lintang pada pasien hemofilia A yang terdaftar pada Himpunan Masyarakat Hemofilia Jawa Barat dari bulan Desember 2012-Juni 2013. Analisis bivariat dilakukan dengan uji chi-kuadrat dan uji t.

Hasil. Terdapat 85 pasien hemofilia A yang mendapat terapi koate ${ }^{\circledR}$. Prevalensi inhibitor $81,13 \%$ (69/85), usia inhibitor positif $9,96(6,49)$ tahun dan inhibitor negatif $8,69(3,87)$ tahun. Hubungan faktor risiko usia pertama kali mendapat terapi, jenis hemofilia A, riwayat operasi, dan frekuensi terapi dengan inhibitor faktor VIII pada pasien hemofilia A berturut-turut adalah $\mathrm{p}=0,512 ; \mathrm{p}=0,202 ; \mathrm{p}=0,663 ; \mathrm{p}=0,276$.

Kesimpulan. Faktor risiko non-genetik tidak berhubungan dengan inhibitor faktor VIII pada pasien hemofilia A.

Sari Pediatri 2015;17(2):119-23.

Kata kunci: faktor risiko non-genetik, hemofilia A, inhibitor faktor VIII

\section{Non-Genetic Risk Factors of FVIII Inhibitor Formation in Hemophilia A Patients}

\author{
Ahmad Saifudin, Harry Raspati Achmad, Lelani Reniarti
}

Background. The formation of FVIII inhibitor in hemophilia A is multifactorial, consists of genetic, environmental factors, which possibly disrupts exogenous FVIII therapy. Few studies have been conducted to find the risk factors of inhibitor formation, however some controversies remain.

Objective. To determine non-genetic risk factors of FVIII inhibitor formation in hemophilia A patients

Methods. Cross sectional study on 85 hemophilia A patients from December 2012-June 2013. Bivariate analysis was performed using chi-square and t-test.

Results. There were 85 hemophilia A patients who received koate ${ }^{\circledR}$ therapy. The prevalence of inhibitor was found in $81.13 \%$ (69/85), with mean age of positive and negative inhibitor formation was $9.96(6.49)$ and 8.69 (3.87) years old, respectively. Association of risk factors such as age at first time therapy was given, severity and type of hemophilia $\mathrm{A}$, history of surgery, and frequency of therapy with FVIII inhibitor in hemophilia A patients were $p=0.512, p=0.202, p=0.663$, and $p=0.276$ respectively. Conclusion. Non-genetic risk factors are not associated with FVIII inhibitor formation in hemophilia A patients. Sari Pediatri 2015;17(2):119-23.

Keywords: factor VIII inhibitor, hemophilia A, non-genetic risk factors

Alamat korespondensi: Dr. Ahmad Saifudin. Departemen Ilmu Kesehatan Anak Fakultas Kedokteran Universitas Padjadjaran/Rumah Sakit Dr. Hasan Sadikin Jl. Pasteur No.38 Bandung 40163, Indonesia. Telp. +62 22-3035957. E-mail: ahmad_gombong@yahoo.com 
$\mathrm{T}$ erapi pengganti pada pasien hemofilia A dengan faktor VIII (FVIII), baik rekombinan maupun plasma, bertujuan untuk mencapai keadaan hemostasis. ${ }^{1}$ Terapi FVIII menjadi tidak efektif apabila pada pasien hemofilia A timbul aloantibodi terhadap FVIII (inhibitor). Inhibitor merupakan imunoglobulin G yang dapat menetralisir aktivitas FVIII pada pasien hemofilia A. ${ }^{2}$ Inhibitor akan meningkatkan biaya yang diperlukan untuk tata laksana pasien hemofilia karena itu diperlukan obat hemostatik alternatif lain. Sampai saat ini, inhibitor masih menjadi komplikasi serius dengan peningkatan morbiditas dan berkurangnya kualitas hidup pasien hemofilia. ${ }^{3,4}$

Inhibitor timbul sering kali tidak disadari dan pada umumnya ditemukan pada saat timbul perdarahan yang sulit diatasi dengan tata laksana biasa atau ditemukan secara kebetulan pada saat pemeriksaan rutin. ${ }^{2}$ Proses terbentuk inhibitor faktor VIII bersifat multifaktorial, dapat dibagi menjadi faktor genetik dan lingkungan. ${ }^{5,6}$ Beberapa penelitian telah dilakukan untuk mengetahui faktor yang berperan terhadap timbulnya inhibitor, tetapi masih terdapat perbedaan pendapat. ${ }^{7-9}$ Evaluasi kadar inhibitor seharusnya dilakukan setiap tahun, tetapi tidak dapat dilakukan karena sarana pemeriksaan yang terbatas dan biaya yang mahal.

Pada pasien hemofilia A di Indonesia, penelitian inhibitor masih terbatas dan menggunakan subjek penelitian yang sedikit. Tujuan penelitian ini adalah untuk mengetahui faktor risiko non-genetik: usia pertama kali mendapat FVIII, jenis hemofilia A, frekuensi terapi FVIII, dan tindakan operasi berperan terhadap terbentuknya inhibitor FVIII.

\section{Metode}

Penelitian bersifat observasional analitik dengan rancangan potong silang yang dilakukan pada bulan Desember 2012-Juni 2013. Kriteria inklusi penelitian ini adalah pasien sudah terdiagnosis hemofilia $\mathrm{A}$ dan mempunyai data kadar FVIII, hanya mendapat terapi koate, dan pasien hemofilia A yang berasal dari penelitian disertasi. Pengaruh tumor nekrosis faktor- $\alpha$ serum dan polimorfisme $-308 \mathrm{G}>\mathrm{A}$ gen tumor nekrosis faktor- $\alpha$ pada terbentuknya antibodi inhibitor FVIII pasien hemofilia A berat. Kriteria eksklusi adalah adanya penyakit perdarahan yang lain (defisiensi vitamin $\mathrm{K}$, koagulasi intravaskular disseminata).

Penelitian telah mendapat persetujuan Komite Etik Penelitian Kesehatan Fakultas Kedokteran Universitas Padjadjaran/RSUP Dr. Hasan Sadikin Bandung dan persetujuan keikutsertaan penelitian didapatkan dari orangtua/wali pasien. Data penelitian diperoleh dari anamnesis, pemeriksaan fisis, dan data rekam medis. Pemeriksaan inhibitor menggunakan metode Bethesda assay di laboratorium patologi klinik RSHS dengan alat STACO. Pemeriksaan dilakukan dengan mencampurkan plasma individu normal dengan subjek dan diinkubasi selama dua jam pada suhu $37{ }^{\circ} \mathrm{C}$. Dilakukan pemeriksaan aktivitas kadar faktor VIII, kemudian disesuaikan dengan kurva untuk mendapatkan nilai inhibitor dalam Bethesda unit (BU). Inhibitor negatif didefinisikan apabila aktivitas residual FVIII lebih dari 75\%. Satu BU didefinisikan sebagai faktor VIII yang menginaktifkan 50\% jumlah awal kadar FVIII dalam plasma normal.

Penilaian terhadap faktor risiko usia pertama kali mendapat FVIII, jenis terapi penggganti FVIII, jenis hemofilia A, frekuensi terapi FVIII, dan tindakan operasi menggunakan analisis bivariabel dengan uji chikuadrat dan uji t. Analisis multivariat tidak dilakukan karena tidak memenuhi syarat.

\section{Hasil}

Di antara 104 pasien hemofilia terdapat 85 pasien hemofilia A yang dalam anamnesis dan rekam medis hanya mendapat terapi koate, terdiri atas 85 pasien hemofilia A, 66 hemofilia A berat, 15 hemofilia A sedang, dan 4 subjek merupakan hemofilia A ringan. Terdapat 69 subjek dengan inhibitor positif $(81,0 \%)$. Karakteristik subjek penelitian tertera pada Tabel 1 . Usia pasien hemofilia A pada saat penelitian pada inhibitor positif dan negatif tidak terlalu berbeda. Sekolah dasar merupakan mayoritas pendidikan subjek penelitian dengan suku bangsa ibu, Sunda, merupakan suku terbanyak baik pada inhibitor positif maupun negatif.

Tabel 2 menunjukkan tidak ada hubungan faktor risiko nongenetik (usia pertama kali mendapat FVIII, jenis hemofilia A, riwayat tindakan operasi, dan frekuensi terapi (kali/bulan) dengan terbentuknya inhibitor faktor VIII $(\mathrm{p}>0,05)$. 
Tabel 1. Karakteristik pasien hemofilia A dan orangtua

\begin{tabular}{lcc}
\hline \multirow{2}{*}{ Variabel } & \multicolumn{2}{c}{ Inhibitor } \\
\cline { 2 - 3 } & $\begin{array}{c}\text { Negatif } \\
(\mathrm{n}=16)\end{array}$ & $\begin{array}{c}\text { Positif } \\
(\mathrm{n}=69)\end{array}$ \\
\hline Usia saat ini (tahun) & $8,69(3,87)$ & $9,96(6,49)$ \\
Pendidikan & 2 & 10 \\
$\quad$ Belum sekolah & 8 & 4 \\
Taman kanak kanak (TK) & 6 & 35 \\
Sekolah dasar (SD) & - & 12 \\
SMP & - & 6 \\
SMA & - & 2 \\
Diploma/sarjana & & \\
Suku bangsa ibu & 15 & 62 \\
Sunda & 1 & 5 \\
Jawa & - & 1 \\
Batak & - & 1 \\
Minang & - & - \\
Palembang & & \\
Suku bangsa ayah & 14 & 55 \\
Sunda & - & 9 \\
Jawa & - & 1 \\
Batak & - & 2 \\
Minang & - & 1 \\
Palembang & & \\
Aceh & & \\
\hline & & \\
\hline
\end{tabular}

\section{Pembahasan}

Penelitian kami merupakan penelitian inhibitor FVIII pertama kali pada populasi hemofilia A di Jawa Barat. Secara khusus, penelitian menentukan faktor risiko non-genetik (fenotip) yang berperan pada terbentuknya inhibitor pasien hemofilia A yang hanya mendapat terapi koate. Hasil penelitian kami menunjukkan tidak terdapat hubungan faktor nongenetik (usia pertama kali mendapat faktor VIII, jenis hemofilia, riwayat tindakan operasi, dan frekuensi terapi) dengan terbentuknya inhibitor FVIII.

Prevalensi inhibitor subjek adalah 81,0\% (69/85), Prevalensi inhibitor FVIII pada pasien hemofilia A bervariasi, tetapi secara keseluruhan berkisar 3,6\%$52 \%$. Penelitian mengenai prevalensi inhibitor di negara Asia, berturut turut adalah Taiwan 10,4\%, Cina 1,4\%, Jordania 9\%, dan Saudi Arabia 9,7\%. Penelitian Simatupang $\mathrm{dkk}^{10}$ mendapatkan prevalensi inhibitor $37,5 \%$ dengan sebaran 0,3-88 BU. Sementara penelitian Harijadi $\mathrm{dkk}^{11}$ mendapatkan prevalensi inhibitor 35\%.

Penelitian Hay $\mathrm{dkk}^{12}$ melaporkan insiden inhibitor tertinggi dan tersering pada usia $0-4$ tahun dan $>60$ tahun. Penelitian Gouw dkk, ${ }^{13}$ terhadap 574 pasien

Tabel 2. Hubungan faktor risiko nongenetik inhibitor FVIII

\begin{tabular}{lccc}
\hline \multirow{2}{*}{ Parameter } & \multicolumn{2}{c}{ Inhibitor } & \\
\cline { 2 - 3 } & $\begin{array}{c}\text { Negatif } \\
(\mathrm{n}=16)\end{array}$ & $\begin{array}{c}\text { Positif } \\
(\mathrm{n}=69)\end{array}$ & $\mathrm{p}$ \\
\hline Usia pertama kali mendapat terapi (tahun) & $3,25(3,58)$ & $4,85(4,26)$ & $0,512^{*}$ \\
Jenis hemofilia A & & 4 & \\
$\quad$ Ringan & 0 & 10 & $0,202^{\#}$ \\
$\quad$ Sedang & 5 & 55 & \\
$\quad$ Berat & 11 & 39 & $0,663^{\#}$ \\
Riwayat operasi & & 30 & \\
$\quad$ Ya & 10 & & \\
$\quad$ Tidak & 6 & 11 & $0,276 \#$ \\
Frekuensi terapi ( kali/bulan) & & 2 & \\
$\quad<1$ & 0 & 36 & \\
1 & 1 & 20 & \\
2 & 8 & & \\
$>2$ & 7 & & \\
\hline
\end{tabular}

$\mathrm{p}<0,05$, *uji t, \# uji chi-kuadrat 
hemofilia A berat yang lahir antara tahun 2000 sampai dengan 2010, mendapatkan 177 (32,4\%) anak mempunyai kadar inhibitor positif.

Usia pertama kali mendapat terapi faktor VIII tidak berbeda pada inhibitor positif dan negatif. Sampai saat ini, peran usia pertama kali mendapat FVIII terhadap terjadinya inhibitor masih diperdebatkan. Beberapa penelitian mengelompokkan usia pertama kali mendapat terapi FVIII menjadi 0-6 bulan, 6-12 bulan, dan di atas 1 tahun mendapatkan hubungan antara usia mendapat terapi FVIII dan terjadinya inhibitor. Hasil penelitian kasus kontrol oleh Maclean dkk, ${ }^{14}$ dengan pemantauan selama 25 tahun (1982-2007), tidak mendapatkan hubungan antara usia saat mendapat FVIII dan terjadinya inhibitor. Hasil penelitian kasus kontrol yang dilakukan Sagostino $\mathrm{dkk},{ }^{15}$ terhadap 183 anak pasien hemofilia, juga mendapatkan hasil yang sama dengan penelitian Maclean dkk. Penelitian van der Bom dkk ${ }^{16}$ mendapatkan paparan pertama kali terhadap FVIII pada usia $<6$ bulan dan berhubungan dengan risiko tinggi terjadinya inhibitor di kemudian hari.

Penelitian kohort yang dilakukan Gouw dkk ${ }^{17}$ mendapatkan insiden kumulatif terjadinya inhibitor lebih tinggi sesuai dengan usia pertama kali mendapat FVIII, yaitu $<1$ bulan (41\%), $1-6$ bulan $(30 \%)$, 6-12 bulan (23\%), 12-18 bulan (20\%), setelah usia 18 bulan (18\%). Hubungan antara usia pertama kali mendapat FVIII dan terjadinya inhibitor menjadi tidak bermakna apabila faktor perancu seperti intensitas terapi diikutkan dalam perhitungan statistik. ${ }^{8,18}$

Pada penelitian kami, sebagian besar subjek merupakan pasien hemofilia A berat. Kami tidak menemukan hubungan antara jenis hemofila dan terjadinya inhibitor. Berbeda dengan penelitian sebelumnya, pasien hemofilia A berat mempunyai risiko lebih besar untuk terjadinya inhibitor dibandingkan dengan hemofilia A sedang dan ringan. Prevalensi inhibitor secara keseluruhan 10\%-15\%. Pada pasien hemofilia A berat, prevalensi terjadinya inhibitor $20 \%-52 \%$, dibandingkan dengan hemofilia ringan atau sedang (3\%). Pasien hemofilia A berat dengan inhibitor positif lebih sering ditemukan mutasi gen intron 22. Penelitian Goudemand $\mathrm{dkk}^{19}$ serta Chalmers $\mathrm{dkk}^{20}$ pada ras Kaukasian dan Hispanik mendapatkan hasil yang sama.

Tindakan operasi tidak berhubungan dengan terjadinya inhibitor faktor VIII pada pasien hemofilia
A. Hasil penelitian Santagostino dkk, ${ }^{15}$ dengan desain kasus-kontrol, tidak mendapatkan perbedaan prevalensi tindakan bedah baik pada kelompok dengan inhibitor maupun tanpa inhibitor. Hasil berbeda didapatkan pada penelitian retrospektif yang dilakukan oleh Gouw $\mathrm{dkk}^{17}$ yang menyimpulkan bahwa tindakan operasi meningkatkan risiko terjadinya inhibitor.

Tidak terdapat perbedaan frekuensi terapi dengan terjadinya inhibitor. Semua subjek pada penelitian kami mendapatkan terapi FVIII koate. Terapi diberikan apabila terdapat keluhan/gejala (on demand). Pasien hemofilia A yang mendapat terapi pengganti FVIII reguler mempunyai risiko lebih rendah untuk terjadinya inhibitor. Perdarahan hebat dan tindakan bedah berhubungan dengan kerusakan sel nekrotik yang akan merangsang aktivasi sistem imun. Upaya untuk menghindari nekrosis sel, diperlukan pemberian terapi FVIII di luar terdapatnya gejala klinis (terapi profilaksis). ${ }^{8}$

Perbedaan hasil beberapa penelitian tersebut karena perbedaan desain penelitian, jumlah sampel, jenis terapi pengganti yang diberikan atau mutasi gen tertentu. Jenis mutasi gen, lebih sering terjadi pada pasien yang mendapat terapi pada usia dini, adalah intron 22 inversions sehingga diduga mutasi gen tersebut yang paling memengaruhi timbulnya inhibitor. Pasien hemofilia A yang mendapat terapi pengganti FVIII pada usia sangat muda mempunyai kecenderungan perdarahan lebih sering sehingga aktivasi sistem imun lebih sering terjadi. ${ }^{6}$

Penelitian ini memiliki beberapa keterbatasan. Penelitian ini menggunakan metode potong lintang sehingga pengambilan darah untuk pemeriksaan kadar inhibitor dilakukan hanya satu kali dan satu waktu. Dengan motode tersebut, kadar inbititor tidak dapat dibedakan suatu inhibitor transien. Pengambilan sampel darah subjek penelitian juga tidak memperhitungkan interval waktu pemberian koate sebelumnya. Risiko terbesar terjadinya inhibitor pada pasien hemofilia A berat pada usia rata-rata 1-2 tahun (setelah 9-12 terapi) dan terjadi dalam 50 hari pertama setelah terpapar FVIII. ${ }^{21}$

\section{Kesimpulan}

Usia pertama kali mendapat FVIII, jenis hemofilia, tindakan operasi, dan frekuensi terapi FVIII bukan merupakan faktor risiko terjadinya inhibitor. 


\section{Daftar pustaka}

1. Giordano P, Franchini M, Lassandro G, Faienza MF, Valente R, Molinari AC. Issues in pediatric haemophilia care. Italian J Pediatr 2013;39:1-5.

2. The World Federation of Hemophilia. Diagnosis and management of inhibitors to factor VIII and IX: an introductory discussion for physicians. California: The World Federation of Hemophilia; 2004.

3. Gringeri A, Mantovani LG, Scalone L, Mannucci PM. Cost of care and quality of life for patients with hemophilia complicated by inhibitors: the COCIS Study Group. Blood 2003;102:2358-63.

4. Morfini M, Haya S, Tagariello G. European study on orthopaedic status of haemophilia patients with inhibitors. Haemophilia 2007;13:606-12.

5. DiMichele DM. Inhibitors in childhood hemophilia A: genetic and treatment-related risk factors for development and eradication. Pediatr Blood Cancer 2013;60:30-3.

6. Astermark J, Altisent C, Batorova A, Diniz M, Gringer A, Holme P, dkk. Non-genetic risk factors and the development of inhibitors in haemophilia: a comprehensive review and consensus report. Haemophilia 2010;16:747-66.

7. Ragni MV, Ojeifo O, Feng J, Yan J, Hill KA, Sommer SS, dkk. Risk factors for inhibitor formation in hemophilia: a prevalent case-control study. Haemophilia 2009;15:1-8.

8. Chambost H. Assesing risk factors: prevention of inhibitors in haemophilia. Haemophilia 2010;16:10-5.

9. Astermark J. Inhibitor development: patient-determined risk factors. Haemophilia 2010;16:66-70.

10. Simatupang GNA, Windiastuti E, Oswari H. faktor risiko timbulnya inhibitor faktor VIII. Sari Pediatri 2013;15:320-6.

11. Harijadi, Gatot D, Akib A. The prevalence of factor VIII inhibitor in patients with severe hemophilia A and its clinical characteristics. Paeditica Indonesiana
2005;45:171-81.

12. Hay CR, Palmer B, Chalmers E, Liesner R, Maclean R, Rangarajan S, dkk. Incidence of factor VIII inhibitors throughout life in severe hemophilia $A$ in the United Kingdom. Blood 2011;117:6367-70.

13. Gouw SC, Bom JGvd, Ljung R, Escuriola C, Cid AR, Donadel SC, dkk. Factor VIII products and inhibitor development in severe hemophilia A. N Engl J Med 2013;386:231-9.

14. Maclean P, Richards M, Williams M, Collins P, Liesner R, Keeling D, dkk. Treatment related factors and inhibitor in children with severe hemophilia A. Haemophilia 2011;17:282-7.

15. Santagostino E, Mancuso M, Rocino A. Environmental risk factors for inhibitor development in children with hemophilia A: a case-control study. British J Haematol 2005; 130:422-7.

16. Van der Bom J, Mauser-Buncschoten E, Fischer K, Van der Berg H. Age at first treatment and immune tolerance to factor VIII in severe hemophilia. Thromb Haemost 2003;89:46-51.

17. Gouw SC, Bom JGvd, Berg Mvd. Treatment-related risk factors of inhibitor development in previously untreated patients with hemophilia A: the CANAL cohort study. Blood 2007;109:4648-54.

18. Kruse-Jarres R. Current controversies in the formation and treatment of alloantibodies to factor VIII in congenital haemophilia A. Hematology 2011:407-12.

19. Goudemmand J, Rothschild C, Deminguel V, Vinciguerrat C, Lambert T, Chambost H, et al. Influence of the type of factor VIII concentrate on the incidence of factor VIII inhibitors in previously untreated patients with severe hemophilia A. Blood 2006;107:46-51.

20. Chalmers EA, Brown SA, Keeling D, Et.al. Early factor VIII exposure and subsequent inhibitor development in children with severe haemophilia A. Haemophilia 2007;13:149-55.

21. Dimichele DM. Inhibitors in haemophilia: a primer. World Federation of Haemophilia 2008;7:1-4. 